\title{
Calcium-Activated Potassium Channel Subunit Alpha-1
}

National Cancer Institute

\section{Source}

National Cancer Institute. Calcium-Activated Potassium Channel Subunit Alpha-1. NCI

Thesaurus. Code C101365.

Calcium-activated potassium channel subunit alpha-1 (1236 aa, $138 \mathrm{kDa}$ ) is encoded by the human KCNMA1 gene. This protein plays a role in calcium-dependent potassium transport. 